\title{
The Politics of Credentials: A Commentary and Critique of the Presbyterian Church in Southern Africa
}

\author{
GRAHAM A DUNCAN ${ }^{1}$ \\ University of Pretoria
}

The use of credentials in an ecclesiastical context is a means of assuring that a minister is who he or she claims to be and is therefore trained and qualified to exercise ministry within a particular church tradition as determined by individual denominations. The concept and use of credentials has developed over time. Using primary sources in the main, this article examines the use of credentials as a tool for 'inclusion' or a means of 'exclusion', or both, in the history of the largest Presbyterian church in Southern Africa and its predecessors. The research question under study is to what degree, if any, were credentials used to control ministers and to cleanse and purify the church of radical - such as anti-apartheid - elements?

Keywords: credentials, ministry, Presbyterian Church of South Africa (PCSA)

\section{INTRODUCTION}

The most common form of credential is a document affirming belief, trust that a person is he or she claims to be; it is a testimony of credibility and accreditation, a verification which attests to the qualifications, competence or authority issued to an individual by a third party with a relevant or de facto authority or assumed competence to do so; it is an assurance of authenticity and integrity. In ecclesiastical law, credentials can be compared with ambassadorial credentials, which give authority to act in the name in the issuing body, such as a government. The term first appeared in the period 1425-1475 in the late Middle English word cre-

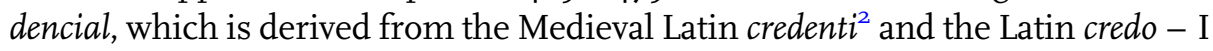
believe. It is therefore an instrument that provides the basis for confidence or belief. In ecclesiastical parlance, credentials refer to 'satisfactory proof of membership' and are referred to as 'satisfactory credentials'3. They have the function of attesting to the good standing of (and absence of discipline against) a minister

1 Thanks are due to emeritus Revd D van Zyl, Revd V Mkungo, Clerk to the General Assembly of the UPCSA, Ms J Botha, Personal Assistant to the General Secretary of the UPCSA, and Mr Justin Taylor, my former research assistant and probationer of the Church of Scotland for their help in securing the various editions of the primary sources for this article.

2 See <http://www.dictionary.com/browse/credential >, accessed 5 December 2016.

3 Presbyterian Church of South Africa (PCSA), Amendments to the Book of Order (Johannesburg, 1960), p 6. 
in another church who applies for recognition as a minister in a different church, and only those who possess the proper credentials are admitted. Credentials convey authority, status, rights and entitlement to privileges when leaving the service of one denomination and moving to another, testifying to the existence of mutual recognition and eligibility of ministries.

Credentials are employed as a means of recognition in many ecclesiastical structures. In hierarchical structures with an episcopal polity, the role of monitoring the movement of ministers is normally vested in one person - the bishop. Communication between bishops tends to be fairly flexible. However, under more representative systems such as the Presbyterian polity, which is governed by courts or councils, there is a greater need for a clearly defined system of accreditation which is both just and equitable, in order to protect ministers and denominations.

\section{CREDENTIALS IN THE SOUTH AFRICAN PRESBYTERIAN SYSTEM}

There were four presbyterian Churches in South Africa during the period of this review. The Presbyterian Church of South Africa (PCSA) was the only whitedominated Presbyterian denomination from its birth in 1897 until its union with the Reformed Presbyterian Church in Southern Africa in 1999. The PCSA developed presbyteries in Zambia and Zimbabwe and changed its name to the Presbyterian Church of Southern Africa in 1959. ${ }^{4}$ Prior to 1897 , the provision for credentials was unnecessary in a body of Presbyterians in South Africa which had no direct connection with one another and no governing body and whose only source of ministers was foreign Presbyterian churches, as no unique South African provision had been made for theological education at this early stage to prepare its own ministerial needs.

From the beginning of Presbyterianism in South Africa, ministers were drawn from Scotland. The earliest example is the ministry of the congregation in Cape Town, whose first minister was the Revd George Thom. However, credentials were not necessary in the period from Thom's arrival in South Africa in $1812^{5}$ until the formation of the PCSA in 1897 , despite the presbyterian form of polity being adopted. ${ }^{6}$ The next minister, after a period of vacancy, was another Scotsman, Dr John Philip from the London Missionary Society. He produced no credentials and managed to enforce a congregational form of polity on the congregation for a period:

See $<$ http://www.archivalplatform.org/registry/entry/presbyterian_church_of_southern_africa/ $>$, accessed 26 January 2017.

5 F Quinn and G Cuthbertson, Presbyterianism in Cape Town: a history of St Andrew's Church, 1829-1979 (Cape Town, 1979), p 3.

6 Ibid, pp 3-4. 
The impression on the mind of Dr Philip appears to be that those who at this time joined the Church constituted a Congregational Church with which the persons previously enrolled in the Presbyterian church were associated; while the church records show that others understood it to be the Presbyterian Church, modified in polity, into which others were received.

Following Philip's brief ministry, a provisional committee was established in order to promote the formation of a Presbyterian congregation, and correspondence ensued between the committee and the Church of Scotland Presbytery of Edinburgh which resulted in the recommendation of James Adamson, who was ordained in 1827 , prior to his departure for South Africa. ${ }^{8}$ In the absence of any formal credentials, the recommendation and ordination constituted the same. Adamson was followed by the Revd George Morgan, a Scotsman 'eminently qualified for such a charge', 9 who had been minister of the Nederduits Gereformeerde Kerk in Somerset East. There is no mention of credentials. During Morgan's tenure at St Andrew's, the Kirk session affirmed its independence of the Church of Scotland in no uncertain terms on 8 November 1843, the year of the Disruption in Scotland:

I. That whereas the Scottish Church in Cape Town has never been so connected with the Church of Scotland as to be represented in her courts, or to be subjected to her jurisdiction and control, and whereas the Church of Scotland has uniformly declined to exercise authoritative jurisdiction over the Presbyterian Churches in the Colonies, even when requested to do so, the Kirk Session consider that the Scottish Church in Cape Town has been left perfectly free to manage its own affairs, or in other words to assume to itself the duties and exercise of power of self-government.

II. That the Kirk Session, having regard to the isolated position of this congregation, the maintenance of peace and unity among its members, the liberality expressed at the hands of the Colonial Government, and the freedom which they have enjoyed in choosing their own Pastor and other Office-bearers, as well as in exercising all rights and privileges without external coercion or interference of any kind, do not deem it necessary in these circumstances to adopt any measure which might affect the present standing or privileges of this church. ${ }^{10}$

7 J Crumbie Brown, Historical Sketch of the Congregational Church Worshipping in Union Chapel (Cape Town, 1847), p 1.

8 Quinn and Cuthbertson, Presbyterianism in Cape Town, $\mathrm{p} 9$.

9 Ibid.

10 Quoted in ibid, pp 26-28. 
Quinn and Cuthbertson are correct in their interpretation that this statement 'gave the colonial Presbyterian autonomy in its decision-making and made it a wholly indigenous denomination, responsible to no higher court than its own'. What is affirmed here is central to Presbyterian polity - the freedom of a congregation to call its own minister. It also meant that the qualifications (academic and otherwise) of those who sought to enter its ministry were subject to the calling body, namely the congregation. This was the background to the formation of the PCSA which, prior to that formation in 1897 , had no specific necessity of a form of credentials.

There is no direct reference to credentials in the Bantu Presbyterian Church of South Africa (BPCSA) Manual of Law, Practice and Procedure in the Bantu Presbyterian Church of South Africa, possibly because it was not necessary since all of its ministers from other churches originated in the Church of Scotland, with whom there was a long-term relationship and mutual acceptance of ministry. This notwithstanding, a provision to admit ministers from other denominations is found in a section of the Manual on the 'Application of ministers of other denominations', which states:

A minister or probationer of another Church, who desired to be admitted as a minister or probationer of this Church, must apply in the first instance to the Presbytery within whose bounds he has taken up residence. The Presbytery has no power to admit him, but must fill up answers to certain questions regarding the applicant, and transmit its answers and his petition to the General Assembly. Where a certificate cannot be obtained without delay which may cause serious inconvenience, a Presbytery is authorised to accept, as equivalent to a certificate from an Assembly, a certificate from the Moderator and Clerk of Assembly, or other persons authorised by the Assembly to grant such a certificate. ${ }^{12}$

The issue of the requirement of a form of credentials is only mentioned when such a form is not available. Hence, the existence of such a provision is presumed. No alteration was ever made to this paragraph (IV.iii.3.3) (13 $^{13}$ during the period of this edition of the Manual (1958-1999), following the Manual of Practice and Procedure of the United Free Church of Scotland (1927). ${ }^{14}$

We now turn to consider the role of credentials in the successive editions of the Book of Order of the PCSA.

$11 \quad$ Ibid, p 28.

12 Bantu Presbyterian Church of South Africa (BPCSA), Manual of Law, Practice and Procedure in the Bantu Presbyterian Church of South Africa (Lovedale, 1958), p 59.

13 Ibid.

14 Ibid, p v. 
The Book of Order of the Presbyterian Church of South Africa, I909 and 1924 The Book of Order provided as follows:

\section{Section VII - Relation to other Churches}

13. Ministers in settled charges of any Presbyterian church in any country are eligible to be called to charges in this Church and may be inducted on production of the proper credentials;

14. Ministers and licentiates in full standing connected with any Presbyterian church in any country may be accepted by presbyteries, on production of proper credentials, as eligible to be called to charges in this Church. ${ }^{15}$

These provisions simply formalised practice both before and after 1897 in the congregations and presbyteries which constituted the union which brought the PCSA into being. They foresaw the continued need for assistance from abroad. The sole provision for entry into the ministry was the production of 'proper' credentials, but the nature of these credentials was not specified. The court of action was the presbytery because this was the court which would exercise care and discipline over the ministers in question. This reminds us of the central role of the presbytery in Presbyterian polity.

In 1925, applications were received from three ministers of other denominations to join the ministry of the PCSA: Congregational, Methodist and Baptist. ${ }^{16}$ No direct mention is made of credentials but phrases appear in the applications and supporting documents which suggest a terminology of credentials: 'that the application be sent on to the Assembly with a strong recommendation that it be granted'; $;$ ' he is in good standing as a minister'; ${ }^{18}$ 'I am asked to send you a line of recommendation'. ${ }^{19}$

The Book of Order was amended in 1941 as follows:

On the resignation of a minister from his pastoral charge:

(14) paragraph 202 is altered to read:

If the resignation be accepted for other reasons, the pastoral tie is dissolved and the pastorate is declared vacant. The Minister remains a minister of the Church, and under its jurisdiction, but, except by express

15 PCSA, The Book of Order of the Presbyterian Church of South Africa (Cape Town, 1909), p 5; PCSA, The Book of Order of the Presbyterian Church of South Africa (Cape Town, 1924), p 5.

16 University of the Witwatersrand, William Cullen Library (hereafter WCL), AC 1971, Ah1.3-1.4, PCSA, General Assembly 1925, pp 148-155.

17 Ibid, p 149

18 Ibid, $\mathrm{p} 153$.

19 Ibid, p 154. 
resolution of the General Assembly, no longer a member of the Presbytery. He may be granted credentials if he so desire, whereupon he ceases to be a minister of the church ... but having no official connection with the congregation in which he last ministered. ${ }^{20}$

Credentials gave a minister status as a minister without charge if he had left a pastoral charge or other church-designated secondment through resignation. The main issue was to dissolve the tie with his previous congregation. The credentialed minister retained his ordained status, though he was outside the discipline of his former denomination, and his freedom to apply for admission to the ministry of another denomination. However, what is confusing is the statement that the minister remains under the jurisdiction of the denomination but is not a member of the presbytery, the court which exercises the denomination's jurisdiction of care and discipline. If he applies for and is granted credentials he becomes 'no longer a minister of the church'. This would suggest a desire on the part of the denomination to exercise control without responsibility 'except by express resolution of the General Assembly'. The assumption is that ceasing to be a minister of the church implies that the individual may choose to serve in another church where certificates are required, credentials to attest status being required for admission to service in other churches.

However, in 1959 we note a direct reference to credentials:

Changes in the ministry...:

The Rev ALC Gray, MA, duly called, brought credentials from the Presbytery of Haddington and Dunbar of the Church of Scotland and was inducted to the pastoral charge at Pinelands on 17 th August $1959 .{ }^{21}$

Acceptance through credentials signified that the ministerial applicant was no longer a member of his previous church. It is not to be assumed that the offering of credentials meant automatic entry into the church's ministry: two applications were declined in 1959; the grounds for denial of status were not specified. ${ }^{22}$

\section{The Book of Order of the Presbyterian Church of South Africa, 1960}

The 1960 edition amended previous provisions thus:

Section VIII - Relation to other Churches

26. Ministers and Licentiates of any Presbyterian Church shall, if in full standing and furnished with satisfactory credentials, be recognised by 
Presbyteries as eligible to be called to charges, or to be appointed to special work in this Church;

Ministers of other Churches, with which mutual eligibility has not been established, may make application to Presbyteries to be received, but such applications may only be granted with the approval of the General Assembly. ${ }^{23}$

It belongs to the presbytery:

231 (20) to accept the resignations of Ministers and other agents of the Church from their charges or other spheres of labour within the bounds, to grant credentials or certificates to them, and to certify to other Presbyteries, ministers, Licentiates and Students for the ministry moving within their bounds. ${ }^{24}$

This is no different from the previous provision for credentials, except that it is recognised that a minister may continue to serve within the church in another capacity or presbytery and, for this, credentials, rather than certificates or letters of transference, are required. This indicates the use of credentials for any movement within or beyond the PCSA. It also signified a change to credentials becoming a matter of authentication within the denomination. This was to be used against ministers whose move to employment outside the denomination was subjected to scrutiny, since it was not stated at that time which types of employment were acceptable. It raised a serious issue regarding the exercise of the ministerial calling, particularly with respect to political involvement in the struggle against apartheid.

Credentials would only apply where mutual eligibility had been established, so a degree of recognition was presumed.

257. The Presbytery shall not accept the resignation of a Minister against whom a judicial process of discipline has been commenced, or respecting whom a public report of a scandalous offence (fama clamosa) is known to exist, provided that, if the resignation be from the ministry of the Church, the Presbytery shall record in its minutes its assessment of the gravity of the prima facie case, and shall determine the conditions as to the granting or withholding of credentials, subject to which conditions the tendered resignation may be accepted. ${ }^{25}$ 
From this it is clear that credentials may not be given to a minister under a charge or under discipline.

297. If a vacant congregation resolve to appoint a commission to select for it a minister having eligibility from a Church in another country, beyond the bounds of the General Assembly ...

298. Subject to his credentials being satisfactory, the Minister selected under such commission is on his arrival within the bounds received as the minister-elect of the congregation and the Presbytery proceeds with his induction as one regularly elected by the congregation. ${ }^{26}$

A minister possessing credentials is assumed to be free from discipline within his former denomination and to meet the requirements for ordination within the PCSA and is eligible for a call. For example:

The Revd AR de Villiers moved that the General Assembly admits the Revd FE Horner as a minister of the Presbyterian Church of Southern Africa, subject to the receipt of credentials from the Congregational Union of South Africa, and provided that he satisfies the Presbytery of Natal concerning his knowledge of the principles and practice of the church. After admission he will be required to serve for a period of two years under the direction of the Church Extension and Aid Committee.

On being put to the vote, the motion was carried. ${ }^{27}$

\section{The Manual of Law, Practice and Procedure in the Presbyterian Church of Southern Africa, $197 \mathbf{1}^{28}$}

By 1971, the section of the Manual of Law, Practice and Procedure on relations with other churches had been removed and references to credentials are subsumed under the chapter on the presbytery. Until this time, credentials had been necessary to ensure the supply of ministers within a growing church which was unable to supply her ministerial needs fully. This may have been the result of the PCSA having by that time become able to sustain its ministry from within its own ranks. From 1870, the PCSA and the Church of Scotland Mission had trained its black ministers at Lovedale Institution. ${ }^{29}$ A change of policy resulted with the opening of the South African Native College at Fort Hare. It was decided in 1925 that the PCSA would train its black students for the ministry at Fort Hare

28 From 1971, the Manual was published in loose-leaf form to take account of the speed of change with regard to developments in church law.

29 A Kerr, Fort Hare, 1915-48: the evolution of an African college (Pietermaritzburg, 1968), p 55. 
because it was considered that 'Uniformity of training for native students as between ourselves and the Bantu [Presbyterian] Church being desirable, the Assembly recommends amalgamation of schemes and the use of facilities provided at Fort Hare. ${ }^{30}$

This co-operation in the training of black ministers persisted in the main until 1993, when the Federal Theological Seminary of Southern Africa closed. ${ }^{31}$ With regard to white candidates for the ministry, training had been carried out on an ad hoc basis until $1918,{ }^{32}$ when a resolution was passed to investigate the possibility of training 'European candidates' at the University of Pretoria. ${ }^{33}$ However, no students registered at Pretoria until 2002. ${ }^{34}$ From 1947, white candidates for the ministry were trained at the newly established Faculty of Divinity at Rhodes University. ${ }^{35}$ Before that time, there was a shortage of South African-trained 'European' ministers, which necessitated the recruitment of ministers from other churches.

Further sections make reference to credentials. The PCSA 'receives ministers without charge certified to it by other Presbyteries'. It appears that certificates were different from credentials and related to ministers within the denomination compared with those outwith its jurisdiction, as it is noted that the PCSA 'grants credentials or certificates where necessary' (no indication is given as to what 'where necessary' means). Finally, 'A minister who so resigns may, if he wish, be granted his credentials, and leave the Church, whereupon he ceases to be a minister of this Church. ${ }^{36}$ Thus credentials were issued to those who intended to leave the church and not to remain in it, even when acting within a different capacity.

On the reverse side, political influences were clearly at work in the period following the Cottesloe Consultation (1960), which led to applications being received from ministers of the Nederduitsche Hervormde Kerk van Afrika (NHKA) to join the ministry of the PCSA as the result of hardening ideas regarding apartheid. As the result of Cottesloe, the NHKA stated unequivocally:

It is our conviction that separate development is the only just solution of our racial problems. We therefore reject integration in any form as a solution of the problem. The agreement that has been reached contains such

31 G Duncan, 'Its end foreshadowed in its beginning: the closure of the Federal Theological Seminary' (2004) 30:1 Studiae Historiae Ecclesiasticae 1-31 at 1.

32 G Duncan, 'Early Presbyterian influences at the University of Pretoria', (2008) 64:1 Hervormde Teologiese Studies $51-71$ at 62 .

33 WCL, AC 1971, Ah1.3-1.4, PCSA, General Assembly, Theological Training Committee, 1918.

34 Duncan, 'Early Presbyterian influences', p 63.

35 P Denis and G Duncan, The Native School That Caused All the Trouble: a history of the Federal Theological Seminary of Southern Africa (Pietermaritzburg, 2011), p 23.

36 PCSA, The Book of Order of the Presbyterian Church of Southern Africa (Johannesburg, 1971), ss 162(g), $162(p)$ and 208. 
far-reaching declarations that we cannot subscribe to it. We can therefore not identify ourselves with it. ${ }^{37}$

An internal war of attrition ensued between supporters of the NHKA's racial position and the growing cadre of opponents who challenged Article 3 of the NHKA's Church Polity on exclusivist racial membership and its opposition to interracial marriages. ${ }^{38}$ Matters came to a head in 1967 , when a significant number of ministers of the NHKA applied for and were granted entry into the ministry of the PCSA on the satisfactory scrutiny of their 'certificates, credentials and relevant documents'. ${ }^{39}$ The ministers admitted were the Revds Prof A van Selms (University of Pretoria), C J Labuschagne (University of Pretoria), J Swanepoel, J A Stoop (University of South Africa), B J van der Merwe (University of South Africa) and J J Coetzee. ${ }^{40}$ The Revds T N du Toit and J P van den Berg were similarly admitted in $1968 . .^{41}$ Not only were they issued with credentials but in Prof van Selms's case 'his ordination of [sic] a $\mathrm{NH}$ Church minister is terminated' ${ }^{42}$ The acceptance of these ministers testified to the relationship which had existed between the PCSA and the NHKA since the foundation of the Faculty of Theology at the University of Pretoria in 1917 , where these two churches were the founding partners. ${ }^{43}$

\section{The Manual of Law and Procedure in the Presbyterian Church of Southern Africa, 1987}

In 1980, the General Assembly clarified its position with regard to credentials and resolved accordingly:

The [Ministry] Committee contacted Presbyterian Churches throughout the world regarding the meaning of credentials and how they operate them. In this regard we found a very great variety of practice but we would like to suggest that we should base our own practice on that of the church [sic] of Scotland, where Presbytery gives Credentials to a minister who is working outside the church. These credentials accredit the minister as having authority to function as a minister for the period of time mentioned on the Credential's Certificate. ${ }^{44}$ 
The Assembly ... [i]nstructs the Committee on the Manual to prepare appropriate amendments to the Manual for submission to the Executive Commission. ${ }^{45}$

This statement made clear that credentials gave a minister accreditation outside the PCSA. This was finalised by the 1985 General Assembly in terms of ministers who retained their churches:

\subsection{7(q) The Presbytery:}

Issues a certificate of credentials (see Appendix $\mathrm{H}(3-5)$ ) (i) to a minister who is seconded in terms of Appendix E(2) and at its discretion to a minister who resigns from his/her charge and becomes otherwise employed outside the jurisdiction of this Church as may be acceptable to the Presbytery of the bounds. Presbytery takes into consideration whether the minister in question continues actively in the work of the Presbytery. ${ }^{46}$

The provision regarding seconded ministers appears to have been honoured in the breach of the regulation rather than in its observance. This marks the beginning of the confusion between the granting of credentials and secondment. The discretionary provision gives significant powers to a presbytery to act against a minister by excluding him or her from exercising ministry while also providing for account being taken of work within the presbytery simultaneously. The crucial issue appears to be that, as soon as the minister in question ceases to work within the church structures, credentials are required:

A minister leaving his charge for other employment places his membership in a congregation within the bounds of the Presbytery under whose care and discipline he/she is placed. Failure to do so shall result in the Certificate of Credentials being withheld. A Certificate of Credentials is normally issued for a period of three years in the first instance and thereafter needs to be renewed annually (Note Appendix E(3)). Application for a renewal of the Certificate of Credentials must be made in writing to the Clerk of the Presbytery of the bounds no later than two months prior to the expiry date of the current Certificate. Such application shall be accompanied by details of present employment and of ministerial functions discharged since the issue of the previous Certificate. Where the information given is not satisfactory or acceptable to the Presbytery, the Presbytery does not renew the Certificate. ${ }^{47}$ 
Here credentials are linked to membership of a congregation. But it is not clear whether credentials remain effective if a minister moves to anther church. Moreover, herein lies a threat, as no indication is given as to what constitutes 'not satisfactory or acceptable'. Therefore the interpretation depends solely on the understanding of the presbytery. For instance, in a presbytery with a definite view of the relationship of church and state, a minister applying for credentials is potentially at the mercy of the presbytery if he or she holds a different view and this is clear from his or her involvement in work outside the church. The implied menace in 5.17(q), above may become a reality. Further, where credentials have not been issued as noted above, an application cannot be made for their renewal. Paragraph 5.63 states: 'A minister who on resigning declares the desire to leave the Church ceases to be a minister of this Church, in which case a Certificate of Credentials will not be issued.'

Appendices $\mathrm{H}(3-5)$ and $\mathrm{E}(3)$ noted above are set out as follows:

Appendix $\mathrm{H}(3-5)^{48}$

THE PRESBYTERIAN CHURCH OF SOUTHERN AFRICA CERTIFICATE OF CREDENTIALS

This is to certify that The Reverend ......

Having resigned from the pastoral charge of ...... to take up employment outside the Church, is recognised by this Presbytery, during the validity of this certificate, to exercise the functions of the ministry in congregations of the Presbyterian Church of Southern Africa.

The certificate is valid until ......

BY ORDER OF THE PRESBYTERY OF ......

Date ...... MODERATOR ...... CLERK

Appendix E(2)

SECONDMENT

(As enacted by 1973 General Assembly)

1. All applications for secondment must be referred to the Consultative Committee on Admissions to the Ministry which reports thereon to General Assembly.

2. Secondment may be considered

a. to ecumenical or multi-church bodies in which this church is either represented or involved;

b. to teaching posts of a theological or religious character;

c. to specialised ministries by this church. 
3. When a secondment is considered due regard must be taken of this Church's own manpower.

4. No secondment shall be made to secular occupations which have no connection with the work and witness of the Church.

Paragraph 5.63 constitutes an anomaly when the minister who leaves the church is not under discipline and wishes to join the ministry of another church. Yet the PCSA expected ministers coming into its ministry from other churches to produce credentials. From this time on, no account was to be taken of work within the presbytery simultaneously if the minister was involved in work where there was no connection with the work and witness of the Church in the secular employment. The implied threat therefore had the potential to become a reality. It is interesting to note that this was the time of the declaration of states of emergency (July 1985 and June 1986) and the increasing involvement of ministers in the struggle against apartheid. A phrase in the abovementioned clause became a source of strong disagreement in terms of what was meant by 'no connection with the work and witness of the Church'. It was to be argued by some within the PCSA that involvement in the struggle against apartheid was of the very essence of the work and witness of the church.

The role of the PCSA in the struggle against apartheid is correctly diagnosed by one of its ministers, the Revd Douglas Bax, who, despite a formidable attempt to defend his church, made the following comments regarding the PCSA's opposition to apartheid:

In spite of the comments that it did make the Church never thought at this stage $(1963-1965)$ of moving from the comfort zone of such statements of protest to the more difficult and costly path of action ... the leaders of the church were white and conservative, and that would have dirtied the church's hands with too direct an involvement in politics. ${ }^{49}$

Relating to the period from 1968, Bax stated, 'Because the majority in the Assembly were always white and because black commissioners were divided, the conservatives [white ministers] managed to block or tone down some attacks on apartheid, but by no means all.' 50

The issuing of credentials provided one means of controlling ministers who had left the direct service of the church to engage in 'secular' service. One significant example is the Revd Makhenkesi A Stofile, who was ordained and seconded to the University of Fort Hare's Faculty of Divinity in 1975. He 
remained there until his resignation in 1987 , when he became a minister without charge..$^{51}$ Stofile's resignation was occasioned by his detention due to his political commitment and this automatically made him persona non grata with many white people in the church who were totally opposed to the presence of ministers in active politics and who used the definition of credentials given in Appendix E(2) to exclude him from further official ministry. In fact, Stofile became bitterly disillusioned as a result of the lack of support from colleagues in the ministry, none of whom visited him during his period in detention. ${ }^{52}$ No concession was made as the result of Stofile's detention and no comment was recorded by what had by that time become the Uniting Presbyterian Church in Southern Africa (UPCSA) regarding the reason for his resignation.

Stofile was, of course, eligible for credentials. This was the use of credentials at its most crass. In 1990 the PCSA General Assembly agreed to a motion stating: 'The Assembly binds ministers of the PCSA not to hold office in any political party. ${ }^{53}$ This referred specifically to office, not membership, and Stofile held office prior to the decision being made and implemented. After the 1994 democratic elections, Stofile was inter alia the African National Congress (ANC)'s chief whip in parliament. He held that position until his appointment as Premier of the Eastern Cape in 1997. He was also Minister of Sport and Recreation, and ambassador to Germany. Interestingly, Stofile continued to exercise his ministry unofficially and regularly accepted invitations to preach until his death in 2016. None of these achievements was officially recognised by the UPCSA. At his funeral on 25 August 2016, his friend and colleague the Revd Blessing B Finca spoke on behalf of the UPCSA and said: 'the church was ashamed of him ... ostracised him ... denied him because of what he stood for' ${ }^{54}$ That referred to a time prior to the union which brought the UPCSA into being, when black colleagues felt intimidated by their white colleagues. When he died, Stofile was accorded a Presbytery funeral as part of a state funeral at which the Moderator of the General Assembly preached, as is the custom.

These 'apartheid' provisions have been maintained in the Manual of Faith and Oder of the UPCSA (2007), which is unfortunate. However, they are challenged by the Confession of Faith of the Church: 'We should each seek our true vocation according to the abilities given to us. Work may be for wages or profit but should also serve God and people, no matter how humbly. ${ }^{55}$ This appears to reflect the lack of threat in a democracy, although the new South African democracy has

$51 \quad$ PCSA, General Assembly minutes, 1990, p C3.

52 Interview with the Revd M E Mtyhobile, December 2017.

53 PCSA, General Assembly minutes, 1987, p 173.

54 Blessing Bongani Finca, address on behalf of the UPCSA at the funeral of the Revd Makhenkesi A Stofile, <https://www.youtube.com/watch?v=IejTx9T88a4>, accessed 18 January 2017.

55

UPCSA, Manual of Faith and Order of the UPCSA (Johannesburg, 2007), \19.1. 
attracted ministers from a variety of denominations to high office in the ANC government. To date, Stofile has been the only UPCSA minister involved and, as we have seen, he remained persona non grata.

Appendix E(3), of the 1980 Year Book, is set out as follows:

1. Credentials, authorising the continued exercise of the functions of the ministry within congregations of this Church, are given by a Presbytery to an ordained minister of this Church who on resigning from a pastoral charge, remains a minister of this Church and is

a. seconded in terms of para 2 of Appendix E (2), to work outside the Church, or,

b. becomes otherwise employed, outwith the jurisdiction of this Church, as may be acceptable to the Presbytery of the bounds.

2. A Certificate of Credentials is issued to such minister, always provided that he/she has placed his/her membership with a congregation within the bounds of the Presbytery under whose care and discipline he/she is placed (see para 5.17(q) and appendix $\mathrm{H}(3)-(5)$.)

3. A Certificate of Credentials is valid only for the specific period of time stated thereon. At any time during the validity of the Certificate it is competent for the holder to receive a call or accept an appointment, as the case may be, to a charge within this Church. At its discretion the Presbytery may withdraw the certificate at any time.

4. An ordained minister who on retirement has been granted by the General Assembly the status of Minister Emeritus does not require a Certificate of Credentials and is exempt from the foregoing regulations.

There is a contradiction here between Appendix E(2)4 and $\mathrm{E}(3) 1 \mathrm{~b}$ and 2 above in terms of what is 'acceptable to the presbytery'. This suggests a lack of consistency even within the same edition of the Manual. It also suggests a degree of uncertainty regarding the issue of secular work and its status. The PCSA received a report from a minister on confusion arising out of difficulty in interpreting the regulations on credentials:

Our church moved from a situation where the granting of a certificate of Credentials meant severance from the church to a situation where the certificate of Credentials affirmed a minister's link with the church. The switch over, however, was not as smooth as it could have been. It appears that the sentence in question: 'At any time during the validity of the certificate it is competent for the holder to receive a call or accept an appointment, as the case may be, to a charge within this Church' was inserted to reassure those used to the previous situation where a minister 
who had received a certificate of Credentials in the category of a minister eligible for a call. Some presbyteries are reading this clause as if it excluded all those who do not have a certificate of Credentials from eligibility to receive a call. In removing this sentence we leave the matter as it was intended, that all ministers of the church are eligible for a call. ${ }^{56}$

This was followed by two proposals: first that a certificate of credentials be valid only for the specific period of time (with the presbytery having discretion to withdraw the certificate at any time); and second that the granting of a secondment be only to the specific occupation or employment defined in the appointment. Its continuation would at all times be subject to the discretion of the General Assembly.

Here we note the link between secondment and credentials. This was a complex matter. In 1989 , a problem arose with regard to ministers from presbyterian churches in Scotland and the USA serving congregations in the Presbytery of Mashonaland in Zimbabwe without the knowledge of the denomination. The General Assembly resolved that such ministers from eligible churches (member churches of the World Alliance of Reformed Churches) be seconded with no mention of credentials. ${ }^{57}$

An issue arose in 1991 under paragraph 5.63 and appendix E930.1(b) in the Presbytery of Transvaal East, where a commission of enquiry (which has powers of discipline) resolved that it:

1. Issues a severe rebuke to the Rev C V (name withheld).

2. Recommends that he discusses with his lawyer the signing of letters of acknowledgement of debt.

3. Recommends that he seeks with the help of one of his colleagues a deeper and more true understanding of his ministry and his call to it.

4. Resolves that the Presbyterian Church of Southern Africa shall not recommend him as a minister to the Presbytery of Glasgow, since this Presbytery has not yet had sufficient time to work through the issues related to his calling to the ministry with him.

5. Instructs the Interim Moderator of [name of congregation], to write to the creditors, from whom we have received correspondence, informing them that this Presbytery has dealt with this matter as far as mandated by its spiritual responsibility for the Rev C V, and that it will take no further action.

Resolution 4 concerns the withholding of credentials in the context of discipline, which had been outlawed legally. However, the Rev C V was in the process of 
leaving the PCSA, having broken the pastoral tie with his congregation, and he did so subsequently, according to the minutes of General Assembly of the PCSA in 1992:

The Rev C V, minister without charge, left South Africa on 5 November 1991. The Presbytery on the same day, in terms of paragraph 2(e) of Appendix E(3) of the Manual of Law and Procedure, deemed his status as a minister of the Presbyterian Church of Southern Africa to have lapsed..$^{8}$

\section{The Interim Manual of Law and Procedure of the Uniting Presbyterian Church in Southern Africa, 200I}

This dealt with the question of credentials in paragraph 5.20: 'The Presbytery: issues a Certificate of Credentials in accordance with Appendices E(3) and $\mathrm{H}(3)$ para 5.' This statement is followed up in paragraph 5.71:

A minister who resigns from the ministry of this church ceases to be a minister in it, and the pastoral tie is dissolved from the date of resignation, unless the Presbytery sets a different date. No Certificate of Credentials is issued.

This is inconsistent, since the purpose of credentials as stated above is that they are given to ministers upon leaving the service of the denomination.

Appendix E(3) is devoted to credentials and is included in the 2007 Manual as Chapter 16 Section B - Credentials. For the first time, credentials are issued to probationer ministers. This is the equivalent of what was previously designated as a Certificate of License. This was reinstated in the 2007 Manual in Appendix $\mathrm{C}(4) 3$.

\section{The Manual of Faith and Order of the Uniting Presbyterian Church in Southern} Africa, 2007

When union negotiations between the PCSA and the United Congregational Church in South Africa (UCCSA) began in 1983, an earlier agreement on the mutual eligibility of ministers was maintained. The provisions for credentials are amply set out in Chapter 16, Section 8 of the 2007 Manual:

Section 8 - credentials

16.123. Credentials certify that a person who has been ordained or received into the ministry of The Uniting Presbyterian Church in 
Southern Africa remains under the care and discipline of one of its Presbyteries and is authorised to continue exercising the functions of the ministry within congregations of The Uniting Presbyterian Church in Southern Africa, even though he/she is not serving in a post in The Uniting Presbyterian Church in Southern Africa to which he was inducted or appointed or seconded to an approved post beyond the jurisdiction of The Uniting Presbyterian Church in Southern Africa.

16.124. A Minister's status as such in The Uniting Presbyterian Church in Southern Africa shall be considered to have lapsed, and can only be reinstated by formal application through the Ministry Committee, for readmission by the General Assembly if:

a) he/she within a period of 60 days after he/she has resigned or left an appointment or charge, has not made a written request for credentials, or for a transfer from the Presbytery within which he/she was serving to the care and discipline of another Presbytery; or

b) he/she is transferred to the care and discipline of another Presbytery and fails to present himself/herself to the Moderator and/or Clerk of that Presbytery within 60 days of the date of transfer, to request in writing the issuing of credentials from his/her new Presbytery; or

c) he/she is not a member of a Congregation in the Presbytery under whose care and discipline he/she has been placed or in a Congregation of another Presbytery within whose boundaries he/ she resides; or

d) he/she goes to work and live in another Presbytery under whose care and discipline he/she has been placed, to transfer him/her to the care and discipline of his/her new Presbytery; or

e) he/she is absent from the countries served by The Uniting Presbyterian Church in Southern Africa for more than 90 days without obtaining leave of absence from the Presbytery under whose care and discipline he/she has been placed; or

f) he/she fails to return to one of the countries served by The Uniting Presbyterian Church in Southern Africa within the period of leave of absence (or duly authorised extension thereof), granted by the Presbytery under whose care and discipline he/she has been placed. ${ }^{59}$

g) his/her credentials have been withdrawn, as a result of his/her having been disciplined under the provisions of Chapter 18 of the Manual; or

h) 80 days have expired since his/her credentials expired.

16.125. A minister's status in The Uniting Presbyterian Church in Southern Africa shall not be considered to have lapsed as the result of 
the suspension of his/her right to exercise the ministry of the Word and Sacraments in terms of Chapter 5 .

16.126. Credentials in the form outlined in the Appendix $\mathrm{C}(4) 7$... may only be granted by the Presbytery which has the care and discipline of the Minister at the time of application.

16.127. Credentials are granted for a period of 12 months.

a) The obligation rests on the Minister who has credentials to apply for their renewal to the Presbytery through its Clerk. This must be done in time for the Presbytery to consider the matter before the credentials lapse. The Minister should be present at the relevant meeting.

b) As part of its care and discipline, the Presbytery, through its Clerk, does not hesitate to remind a Minister that his/her credentials are about to lapse. The Moderator and/or Clerk may arrange to meet him/her pastorally to consider the matter before the credentials lapse. The provisions of this sub-para do not affect the obligations on the Minister under (a) above.

c) In granting and renewing credentials Presbytery takes into account the minister's participation in the fellowship and work of the Presbytery, his/her membership of a Congregation within its boundaries, and his/her current occupation.

d) At its discretion the Presbytery may withdraw the Certificate of Credentials at any time. ${ }^{60}$

16.128. At any time during the validity of the certificate it is competent for the holder to receive a Call or accept an appointment, as the case may be, to a charge within this Church.

16.129. An ordained minister who on retirement has been granted by General Assembly the status of Minister Emeritus does not require a certificate of credentials and is exempt from the foregoing regulations.

16.130. A Probationer or Minister appointed as full-time Chaplain is transferred to the care and discipline of a Presbytery appropriate to the area of his/her military service and there, upon his/her written request, is issued with a certificate of credentials specifying his/her status as a military Chaplain and whether he/she is licensed to preach the Gospel or ordained as a Minister of Word and Sacraments. (A Minister desiring to become a military Chaplain applies through the Ministry Committee to the General Assembly for secondment.) ${ }^{61}$

Go Note that, twice in these provisions, the 'discretion' of the Presbytery is emphasised, without clarification being offered regarding what is meant by this and how far this discretion extends.

61 UPCSA, The Manual of Faith and Order of the of the Uniting Presbyterian Church in Southern Africa (Johannesburg, 2007), 16.123-130 and App E(3), para 1. 
A Certificate of Credentials is worded as follows:

This is to certify that the Reverend ... Having resigned from the pastoral charge of ... to take up employment outside the church, has been placed under the care and discipline of this Presbytery and is recognised by the Presbytery as a minister, authorised during the validity of this Certificate, to exercise the functions of the ministry in congregations of The Uniting Presbyterian Church in Southern Africa. ${ }^{62}$

Although it is not explicitly stated, the reverse provision regarding ministers leaving the UPCSA for service in other churches in other countries, would also be true, although this facility was not implemented until PCSA and UPCSA ministers began to be called to charges elsewhere (for example, the United Kingdom), towards the close of the twentieth century and beyond. Chapter 16.123 introduced a regulation on the basis of service performed outwith the jurisdiction of the UPCSA on secondment, such as in a charge of the United Reformed Church in the United Kingdom or the Church of Scotland. These ministries were of longer or shorter duration and some ministers remained in their service; some were called to charges in the USA or Australasia. ${ }^{6}$ Some of these ministers apply annually for credentials, raising the matter of loyalty and commitment as was noted above. Only one of those noted in the 2014 General Assembly Minutes returned to the UPCSA and some subsequently lost their credentials. Some had not even applied for credentials, indicating that they had no intention of returning to the UPCSA. One absconded without informing his presbytery (Amatola) that he was leaving.

This is by no means an exhaustive list of ministers who left the UPCSA, a relatively small church which has a shortage of ministers, and the number involved raises questions as to motivation in leaving the UPCSA at a time in its history when it is engaging in the growth and development of a democratic society. A disturbing aspect of this movement was that two ministers left the service of the UPCSA within a very short time of completing their probation, indicating that they had perhaps been intending to leave while they were still in training. Nor was this a new thing. Some ministers left for shorter periods and subsequently returned. Ministers had moved to churches in other countries before, but the volume of ministers leaving in the 1990 and the first decade and a half of the third millennium gave cause for concern.

The significance of this change is related to the ending of apartheid, where affirmative action (AA) and black employment equity (BEE) (which favoured

62 UPCSA, The Interim Manual of Law and Procedure (Johannesburg, 1999), App H(3) para 5; UPCSA, Manual of Faith and Order (2007), App C(4)7.

63 UPCSA, General Assembly minutes, 2014, pp 5-34. 
black persons) replaced job reservation (which had favoured white persons). In a number of cases, the children of white ministers took gap years or simply moved abroad to find a more congenial career environment, and their parents in the ministry followed. It is strange that, in the recollection of the author, the same white ministers had not challenged job reservation but were vociferous in their condemnation of AA and BEE. Job reservation was recognised as an act of grave injustice in black South African society; yet the PCSA remained silent.

\section{ASSESSMENT}

The issue of the use of credentials in the PCSA was a problematic one. It was a necessary requirement in the recruitment and selection of ministers which was informal up until the formation of the PCSA in 1897, and was gradually and increasingly formalised after that. The motivation was to keep the church's ministry pure and undefiled prior to and after it began to produce its own ministers. Hence, it was a tool for inclusion. Those ministers who did not wish to remain within the care and discipline of the PCSA were free to leave, and left with credentials for the most part. More recently, however, aligned to this group were those ministers who breached the code which prevented ministers from being involved politically in the struggle against apartheid, yet were not subjected to discipline and retained their credentials. Then there were those who used credentials to leave the church for other pursuits for a variety of reasons and those who were selectively excluded owing to their political commitment and involvement. In such cases it is difficult to know how to apply for credentials to serve in another church, while remaining a minister of one's original church but no longer subject to its care and discipline. This was a deviation from the 1941 Book of Order and constitutes a clear anomaly. It was noted that there was an inconsistency between the issue of credentials to those who remain in the service of the denomination, having left their charges, or appointments or secondments, and those leaving it.

\section{Vocation}

For some time there has been confusion over the use of secondment in the UPCSA as a means of continuing the care and discipline of ministers who are appointed to official administrative positions in the denomination, to theological education and to serve outside the officially regarded ministries of the church, such as chaplaincies in the South African Defence Force. ${ }^{64}$ However, a particularly problematic provision is found in 2007 The Manual of Faith and 
Order: 'No secondment shall be made to secular occupations which have no connection with the work and witness of the Church'. ${ }^{65}$ This raises the question: What is not connected with 'the work and witness of the Church'? The Confession of Faith of the UPCSA states in regard to vocation that 'We should each seek our true vocation according to the abilities given to us. Work may be for wages or profit but should also serve God and people, no matter how humbly. 66

For Dietrich Bonhoeffer, discipleship is impossible to understand without vocation, since it is the call of God which makes discipleship possible. One does not decide to follow Christ nor to become Christ's disciple. Rather, 'divine grace comes upon man and lays claim to him. It is not man who seeks out grace in its own place ... but it is grace which seeks and finds man in his place ... and which precisely in this place lays claim to him. ${ }^{67}$ It is not a call to a particular function or status, but a call in the place where we live responsibly:

It is the laying claim to me by Christ at the place at which this call has found me; it embraces work with things and relations with persons; it demands a 'limited field of accomplishments', yet, never as a value in itself, but in responsibility towards Christ. ${ }^{68}$

Somewhat earlier, Bonhoeffer had affirmed that the call issues forth in obedience:

It is a gracious call a gracious commandment. It transcends the difference between the law and the gospel. Christ calls, the disciple follows; that is grace and commandment in one. 'I will walk at liberty, for I seek thy commandments' (Ps 119:45). ${ }^{69}$

This points to a theological and a legal inconsistency in the issue of credentials to those who remain in the service of the denomination and those leaving it.

\section{CONCLUSION}

During the years since the arrival of Scottish Presbyterians in South Africa, ministers have been admitted to ministry in congregations through various forms of credentials. These forms developed over the years to the point where the UPCSA

67 D Bonhoeffer, Ethics (London, 1963), pp 254-255, emphasis in original.

68 Ibid, p 257.

69 D Bonhoeffer, The Cost of Discipleship (London, 1937), p 48. 
finds itself in considerable confusion regarding the nature of credentials. An example was given of the use of credentials to remove a minister for 'political' activities during the apartheid era. In light of the nature of vocation, it would seem that credentials are only necessary for those who leave the UPCSA or those who wish to enter its service from outside the UPCSA. This was the original aim of credentials. If a minister moves within the bounds of the UPCSA, then he or she may simply inform the receiving presbytery of his or her presence and have a letter of transfer issued to the new presbytery under whose care and discipline he or she now falls, in recognition of the many and varied ways of exercising the vocation. This involves a move from prohibitive to permissive legislation. In the light of the above, it is clear that there needs to be some revision of the provision of credentials and this is currently under consideration. 